\title{
Saltcedar (Tamarix ramosissima) Invasion Alters Decomposer Fauna and Plant Litter Decomposition in a Temperate Xerophytic Deciduous Forest
}

\author{
José Camilo Bedano, ${ }^{1,2}$ Laura Sacchi, ${ }^{2}$ Evangelina Natale, ${ }^{3}$ and Herminda Reinoso ${ }^{3}$ \\ ${ }^{1}$ Departamento de Geología, Facultad de Ciencias Exactas, Físico-Químicas y Naturales, \\ Universidad Nacional de Río Cuarto, Ruta 36, Km. 601, X5804 BYA Río Cuarto, Córdoba, Argentina \\ ${ }^{2}$ Consejo Nacional de Investigaciones Científicas y Técnicas (CONICET), C1033AAJ Buenos Aires, Argentina \\ ${ }^{3}$ Departamento de Ciencias Naturales, Facultad de Ciencias Exactas, Físico-Químicas y Naturales, \\ Universidad Nacional de Río Cuarto, Ruta 36, Km. 601, X5804 BYA Río Cuarto, Córdoba, Argentina
}

Correspondence should be addressed to José Camilo Bedano; jbedano@gmail.com

Received 23 June 2014; Accepted 8 August 2014; Published 21 August 2014

Academic Editor: Alistair Bishop

Copyright (C) 2014 José Camilo Bedano et al. This is an open access article distributed under the Creative Commons Attribution License, which permits unrestricted use, distribution, and reproduction in any medium, provided the original work is properly cited.

\begin{abstract}
Plant invasions may alter the soil system by changing litter quality and quantity, thereby affecting soil community and ecosystem processes. We investigated the effect of Tamarix ramosissima invasion on the decomposer fauna and litter decomposition process, as well as the importance of litter quality in decomposition. Litter decomposition and decomposer communities were evaluated in two monospecific saltcedar forests and two native forests in Argentina, in litterbags containing either local litter (saltcedar or dominant native species) or a control litter. Saltcedar invasion produced an increase in Collembola, Acari, and total mesofauna abundance, regardless of the litter type. Control litter decomposition was higher in the native forest than in the saltcedar forest, showing that increased abundance of decomposer fauna does not necessarily accelerate decomposition processes. Local litter decomposition was not different between forests, suggesting that decomposer fauna of both ecosystems is adapted to efficiently decompose the autochthonous litter. Our results suggest that the introduction of a resource with higher quality than the local one has a negative effect on decomposition in both ecosystems, which is more pronounced in the invaded forest than in the native forest. This finding stresses the low plasticity of saltcedar decomposer community to adapt to short-term environmental changes.
\end{abstract}

\section{Introduction}

Saltcedar (Tamarix spp.), a tree native to Eurasia, was introduced to North America, Australia, and Mexico in the mid1800 s for use as an ornamental plant, in windbreaks, and to prevent erosion in arid regions [1,2]. In the last 50 years, saltcedar has spread rapidly along many rivers in North America [1]. In Argentina, the presence of four species of Tamarix has been confirmed: T. gallica L., T. ramosissima Ledebour, T. chinensis Loureiro, and T. parviflora DC. The first three species grow spontaneously and frequently invade natural and seminatural environments, colonizing riparian habitats in arid and semiarid continental zones, and coastal areas. Recent surveys have shown that the genus distribution covers a strip between $49^{\circ} 07^{\prime}$ and $22^{\circ} 91^{\prime} \mathrm{S}$ and $70^{\circ} 03^{\prime}$ and $57^{\circ} 10^{\prime} \mathrm{W}[3]$

Saltcedar invasions are associated with several negative effects that can alter species composition and ecosystems processes. Several impacts have been attributed to saltcedar, such as displacement of native species [1], decline in ecological functions [4], increased frequency of fire [5], lowering of water tables, lower river flow rates and lake levels [1], and soil salinization [5-7]. However, the reported evidences that saltcedaris the main or unique cause of these negative effects are ambiguous $[3,8]$.

Plant communities and the belowground ecosystem are inextricably linked together via carbon input and nutrient flow [9]. Therefore, vegetation regulates the availability of 
resources, influencing the soil physical, chemical, and biological characteristics [10]. Invasive plant species may affect soil surfaces by changing surface microclimates, amount and quality of litter resources, and root exudates made available to soil organisms [9]. Such effects may induce changes in the composition and structure of the soil biota [11], which in turn may affect some ecosystem processes [12-15]. A study about the effects of an invasive herbaceous weed over epigaeic invertebrates found that, of three treatments, two had higher invertebrate abundance in the invaded plots than in the noninvaded plots [11]. Ehrenfeld et al. [16] found that litter decomposition tended to be more rapid under exotic vegetation than under native species because initial $\mathrm{N}$ concentration was higher under the former vegetation type. Ashton et al. [17] also found that litter of diverse species types decomposed substantially faster in invaded sites than in uninvaded sites. However, some studies detected no changes in decomposition rates despite large changes in soil organisms ([13] and references therein). Therefore, to predict and manage the consequences of invasions, a deeper understanding of the effects of exotic species on decomposition processes is essential [17].

Litter decomposition is mainly controlled by climate, litter quality, and decomposer organisms [18-21]. In a given climatic region, litter chemistry parameters are the best predictors of decomposition rate [19]. Litter quality exerts control on the decomposition rate through the effect on abundance and activity of decomposers [22, 23]. However, most studies have failed to identify the soil organisms involved in the decomposition process [18]. It has been suggested that excluding soil faunal activities from current measurements of decomposition rates seriously reduces the likelihood of properly modelling decomposition [24]. Soil organisms influence decomposition processes through litter comminution, which facilitates leaching of several compounds and increases the surface area for bacterial and fungal activities [25-27].

Much of the previous research on effect of saltcedar invasion has focused on water use relative to native plants species, displacement of native vegetation, and the use of saltcedar by native fauna. However, very little attention has been paid to the impacts of saltcedar on the ecosystem processes and the decomposer community. Ashton et al. [17] recommended comparing both native and invasive plant species and decomposer communities associated with invasion to identify the impacts of invasive species at the ecosystem scale. The overall objective of the present work was to evaluate the effects of saltcedar invasion on soil ecosystem functioning. Specifically, the aims were to (1) investigate possible differences in decomposer fauna between saltcedar forests and native forests (five common species), (2) assess if changes in decomposer fauna affect plant litter decomposition processes, and (3) evaluate the relative importance of litter quality in litter decomposition rate.

\section{Materials and Methods}

2.1. Study Sites. The study sites were located in Las Perdices, central-southern Córdoba, Argentina $\left(32^{\circ} 36^{\prime} 47^{\prime \prime} \mathrm{S}\right.$ and $63^{\circ} 39^{\prime} 18^{\prime \prime} \mathrm{W}$ ) (Figure 1). The original vegetation is a xeric deciduous forest composed of species adapted to salt stress, such as Grabowskia duplicata, Geoffroea decorticans (Chañar), Schinus fasciculatus (Moradillo), and Atriplex undulata (Zampa) [28]. Geomorphologically, the region is a High Loessic Plain, with a gently undulating relief. The soil was classified as Entic Haplustoll following Soil Survey Staff [29]. Soil is well to somewhat excessively drained, deep, loamy, with moderate organic matter content and moderate exchange capacity [30]. Precipitation is concentrated in the summer, with an annual mean of $800 \mathrm{~mm}$. Annual precipitation during the study period was 577 and $751 \mathrm{~mm}$ in 2007 and 2008, respectively. The annual mean temperature is $16^{\circ} \mathrm{C}[31]$.

2.2. Methodology. In this area, we selected two patches of each forest type which we considered replicates: monospecific saltcedar patches (1.6 and $2.1 \mathrm{ha}$ ) and native forest patches (1.2 and $2.8 \mathrm{ha}$ ). The four sites have the same soil series (according to Soil Taxonomy classifications) and have similar geomorphological characteristics. Slope (1-3\%) and elevation (approximately $250 \mathrm{~m}$ a.s.l.) were also very similar in the four sites. The distance between the two saltcedar patches was $250 \mathrm{~m}$, and the distance between the two native forest patches was $860 \mathrm{~m}$. Soil organic matter content and soil moisture were higher in the native forest than in the saltcedar forest (organic matter: $7.9 \%$ and $0.9 \%$; moisture: $31.5 \%$ and $16.5 \%$, resp.) whereas $\mathrm{pH}$ values were very similar between saltcedar and native forest (7.89 and 7.83) [32].

Sampling sites were carefully selected to avoid potentially spurious differences among sites other than invasion impact. Until approximately 1960 the four plots had the same landuse history, because they were natural forests [33]. Saltcedar invasion began when the Tegua stream, which flows to the north of the study sites, was channelized in the 1960s and some saltcedar individuals were planted along its margins. At present, saltcedar covers approximately $300 \mathrm{ha}$, and there are some relict patches of the native forest. The native forest had a diverse herb layer that comprised 52 species [34], whereas in the saltcedar forest the herbaceous vegetation was scarcely developed.

We examined decomposition of leaf litter by the litterbag method [35] in a 0.5 ha area in the centre of each forest site. Litter decomposition was calculated based on percent dry mass loss from an initial known weight of plant litter placed in litterbags. The litterbags were $15 \times 15 \mathrm{~cm}$ in size, with a mesh size of $2 \mathrm{~mm}$. Two residue types, placed in separated litterbags, were used: local residues (collected from each site) and control residue (the same in all sites). Local litter from native forest was composed of an equal mix of the five dominant native species. Local litter from saltcedar forest was composed of saltcedar litter only. In the local and control litter, a similar proportion of leaves and twigs were placed in each bag. All residue types were air-dried at $30^{\circ} \mathrm{C}$ for $72 \mathrm{~h}$ before litterbag construction. Six litterbags containing $10 \mathrm{~g}$ of dry litter of the local litter and six litterbags containing the control litter were placed in each patch. The control litter was used to compare decomposition among forest types without 


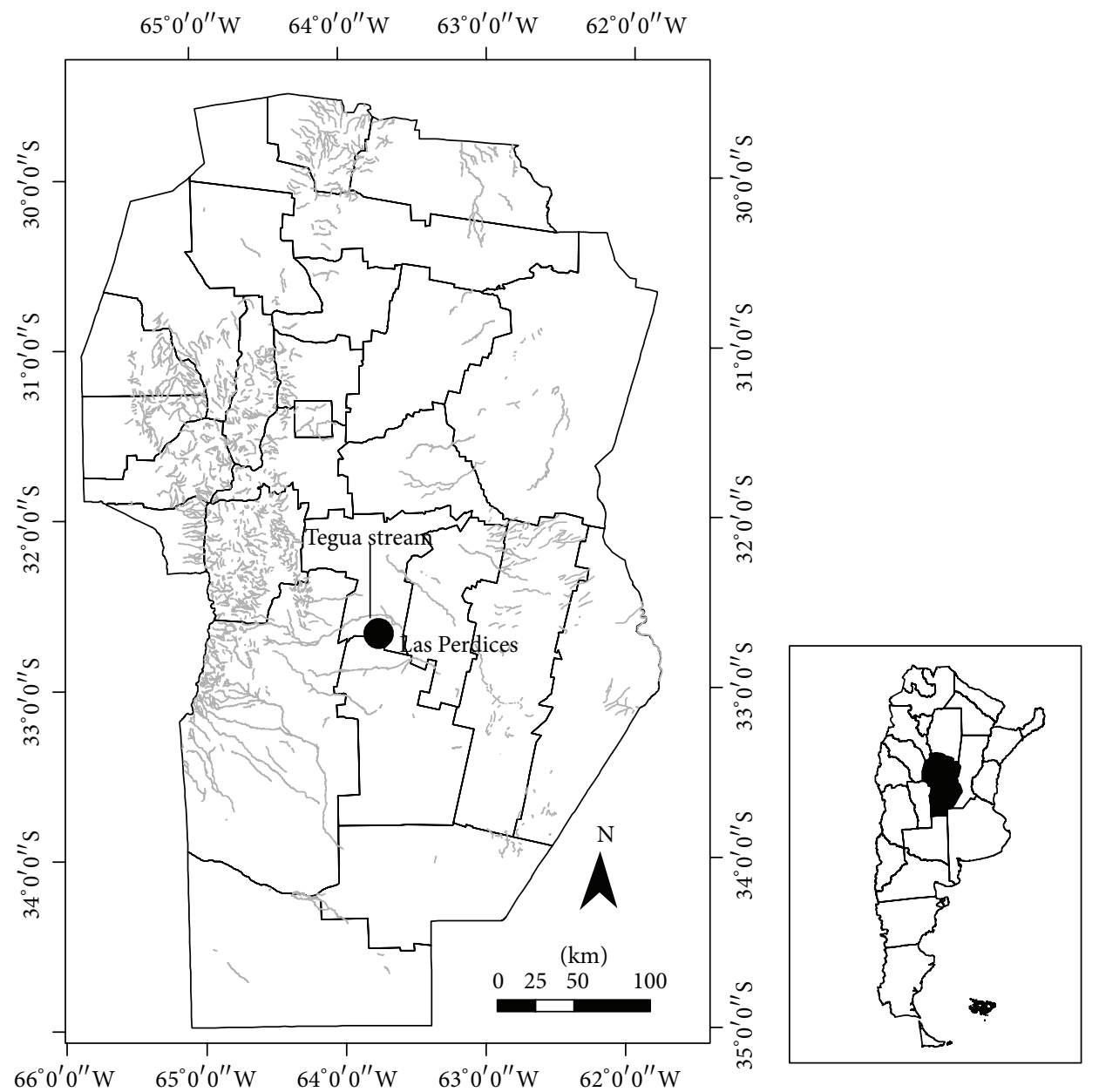

Figure 1: Location of the study area in Las Perdices, Córdoba, Argentina.

the influence of litter quality. As control litter we used alfalfa (Medicago sativa) since it is usually planted in the region [36] with a $\mathrm{C}: \mathrm{N}$ ratio of approximately 10 for leaves and 21 for stems and with low lignin content [37] being therefore a high quality litter.

Litterbags were placed in November 2007 and harvested in May 2008, to ensure that they were in the field during the season of highest activity of decomposer fauna in the region [38]. Litterbags were carefully located separately into plastic bags to avoid residue loss and then transported to the laboratory. The litter remaining in the collected bags was processed in Berlese funnels during 10 days to extract decomposer mesofauna. The organisms obtained were stored in $70 \%$ alcohol and were identified to suborder level for Acari and to order level for Collembola. To evaluate the shifts in trophic groups between the saltcedar and native forests, mesofaunal taxonomic units were a priori assigned to one of two trophic groups according to the literature: microbedetritivores or predators $[35,39,40]$. After mesofaunal extraction, the litter was dried at $60^{\circ} \mathrm{C}$ for 48 hours, cleaned of soil particles, and weighed. Decomposition was calculated as the difference between initial and final weight and expressed as grams remaining of the initial dry mass. Litter quality was evaluated by determining the presence of lignin, tannin, silica, and cellulose in the litter. We randomly collected senescent adult leaves and twigs of the five dominant plant species in the native forest: Atriplex undulata (Moq.) D. Dietr. (Zampa), Geoffroea decorticans (Gill. ex Hook. \& Arn.) Burkart (Chañar), Schinus fasciculatus (Griseb.) I.M. Johnst. (Moradillo), Baccharis salicifolia (Ruiz \& Pav.) Pers. (Chilca), and Celtis ehrenbergiana (Klotzch) Liebm. (Tala) and leaves and twigs of $T$. ramosissima from the invaded forest. The samples were fixed in FAA (95\% ethanol: glacial acetic acid:37-40\% formaldehyde: water; $50: 5: 10: 35, \mathrm{v} / \mathrm{v}$ ) and dehydrated according to the procedures indicated in Johansen [41] using graded solutions of ethanol and xylene. Fully infiltrated tissues were embedded in Histowax (highly purified paraffin wax blended with polymer additives). A series of transverse sections $12 \mu \mathrm{m}$ thick were obtained from the sample blocks using a Minot rotary microtome and were mounted on glass slides with distyrene, tricresyl phosphate, and xylene (DPX). The sections were triple-stained with 
hematoxylin, safranin $\mathrm{O}$, and fast green FCF, as described by Johansen [41]. A standard Zeiss Model 16 microscope was used to assess the histological preparations.

2.3. Data Analysis. To account for the possible differences in mesofaunal abundances between litter types (saltcedar and native) and for each litter type between forests, a generalized linear mixed model (GLMM) was performed and Akaike's information criterion was used to determine the best predictive model. According to the distribution of abundance data, Poisson error distribution and log link function were used. In the selected model, the abundance of fauna (Collembola, Acari, or Mesofauna) was the dependent variables; forest (saltcedar or native) and litter type (local and control) were the fixed factors, whereas the site (replicate of the forest) and the litterbags (replicate in each site) were the random factors. A posteriori tests were performed by the DGC test [42].

Besides, $t$-test was used to test the differences in trophic structure of decomposer fauna. For this analysis, normal distribution of variables was tested with a modified ShapiroWilks test [43]. When distribution was not normal, the variables were log transformed. All statistical analyses were performed using InfoStat software [44].

\section{Results}

3.1. Decomposer Fauna. Mites (Acari) were the most abundant members of the invertebrate decomposer community in all litter samples, comprising $62 \%$ of total microinvertebrates in local litter and $69 \%$ in alfalfa (control) litter in the native forest and $64 \%$ and $65 \%$ of the local and alfalfa litter, respectively, in the saltcedar forest.

Generalized linear mixed model (GLMM) showed that abundances of all decomposer faunal groups were different between forests (Table 1). Collembola (Figure 2) and total mesofauna abundance (Figure 4) were higher in the local than in the control litter in the native but not in the saltcedar forest. Acari abundance (Figure 3) was not significantly different between litter types in each forest. The comparison of litter types between forests showed higher abundances $(P<0.05)$ of Collembola (Figure 2), Acari (Figure 3), and total mesofauna (Figure 4) in saltcedar forest for both litters, local and alfalfa, than in the native forest. Trophic structure of decomposer fauna was not different in the two forests and in the two litter types ( $t$-test, $P>0.05)$, with predators and microbe-detritivores accounting for about 50\% (Figure 5). A slightly higher amount of microbe-detritivores was found in the saltcedar forest, for both local and control litter, than in the native forest, but differences were not statistically significant.

3.2. Decomposition. Decomposition of local litter was not significantly different between saltcedar and native forests, whereas alfalfa decomposition was significantly higher in the native forest than in the saltcedar forest (Table 2). Decomposition did not differ between litter types in the native forest; however, in the saltcedar forest, local litter decomposed faster than alfalfa litter $(P<0.05)$ (Table 2$)$.

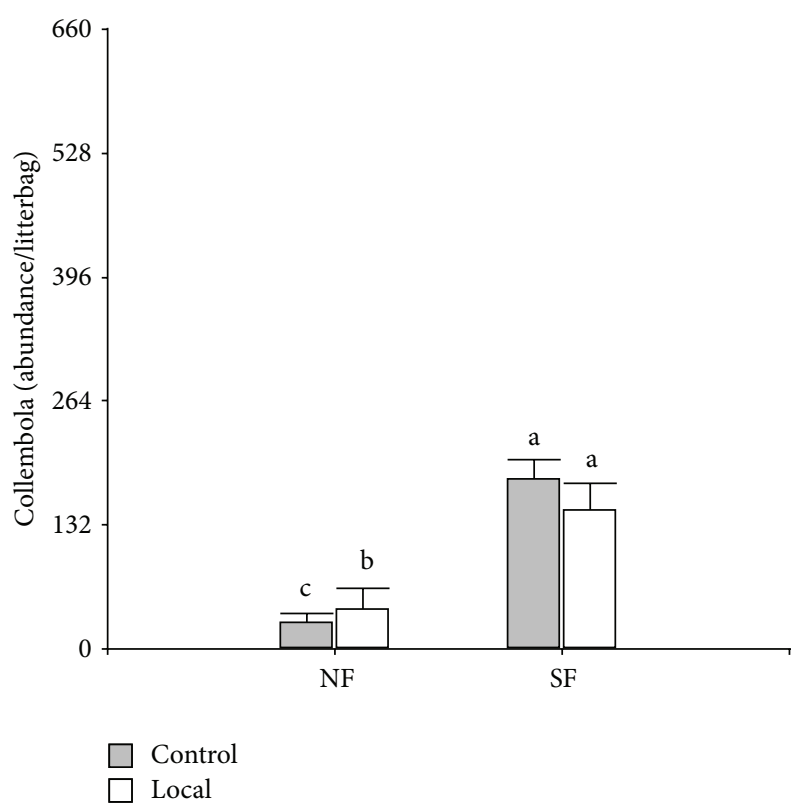

FIGURE 2: Abundance of Collembola in litterbags of local and control litter in the native (NF) and saltcedar (SF, white bars) forests. Error bars represent SD. Bars with the same letter are not statistically different.

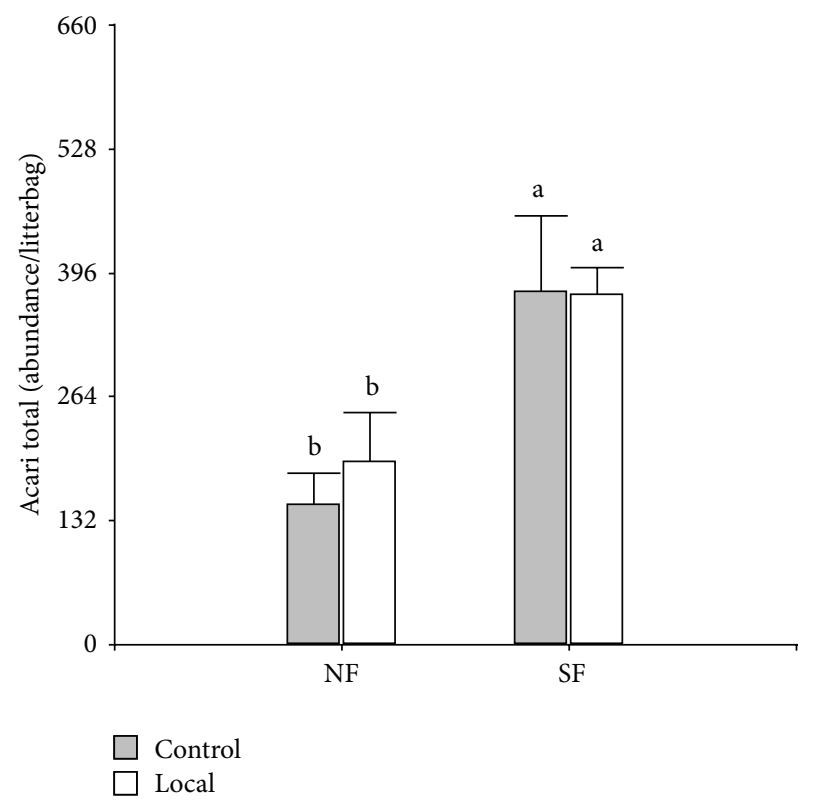

Figure 3: Abundance of Acari in litterbags of local and control litter in the native (NF) and saltcedar (SF) forests. Error bars represent SD. Bars with the same letter are not statistically different.

3.3. Litter Quality. The analysis of litter chemical composition revealed differences in the quality of the litter of the native and the invaded forests. In the native forest, three of the dominant species (G. decorticans, S. fasciculatus, and B. salicifolia) presented tannins as the main compound and lignin as a secondary compound. Lignin was also present in C. ehrenbergiana and A. undulata leaves, although in lower 
TABLE 1: Generalized linear mixed model showing the overall effects of forest type and litter type on the abundance of Collembola, Acari, and total mesofauna.

\begin{tabular}{lcccccccc}
\hline & \multicolumn{3}{c}{ Collembola } & \multicolumn{3}{c}{ Acari } \\
& d.f. & Chi-square & $P$ value & d.f. & Chi-square & $P$ value & d.f. & $\begin{array}{c}\text { Mesofauna } \\
\text { Chi-square }\end{array}$ \\
\hline Forest & 1 & 1375.15 & $<\mathbf{0 . 0 0 0 1}$ & 1 & 1157.55 & $<\mathbf{0 . 0 0 0 1}$ & 1 & 2298.57 \\
Litter & 1 & 3.30 & 0.069 & 1 & 143.72 & $<\mathbf{0 . 0 0 0 1}$ & 1 & 132.71 \\
Forest $*$ litter & 1 & 36.31 & $<\mathbf{0 . 0 0 0 1}$ & 1 & 0.96 & 0.326 & 1 & 5.99 \\
\hline
\end{tabular}

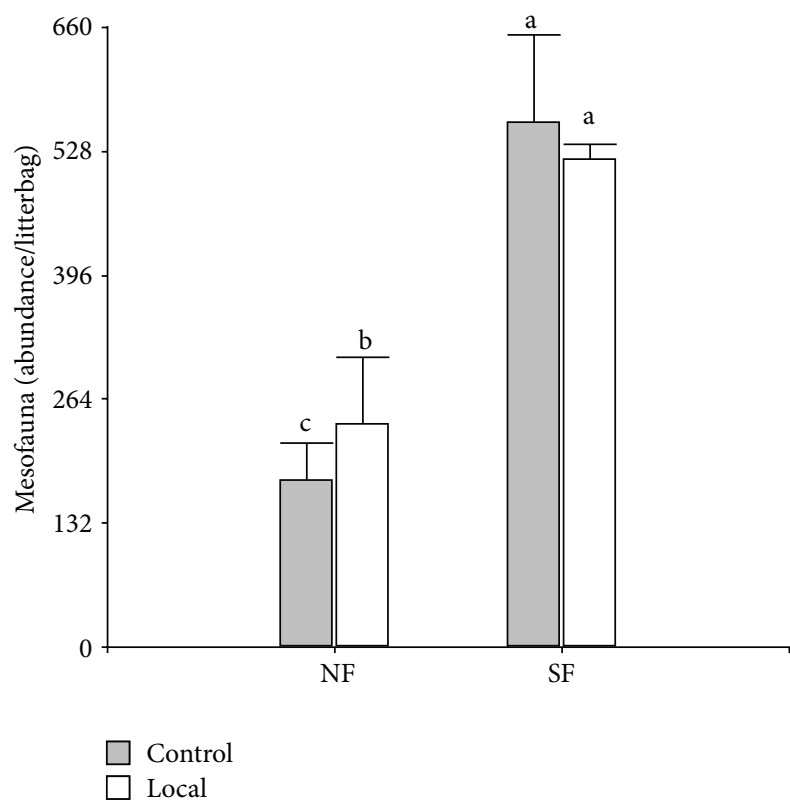

FIGURE 4: Abundance of total mesofauna in litterbags of local and control litter in the native (NF) and saltcedar (SF) forests. Error bars represent SD. Bars with the same letter are not statistically different.

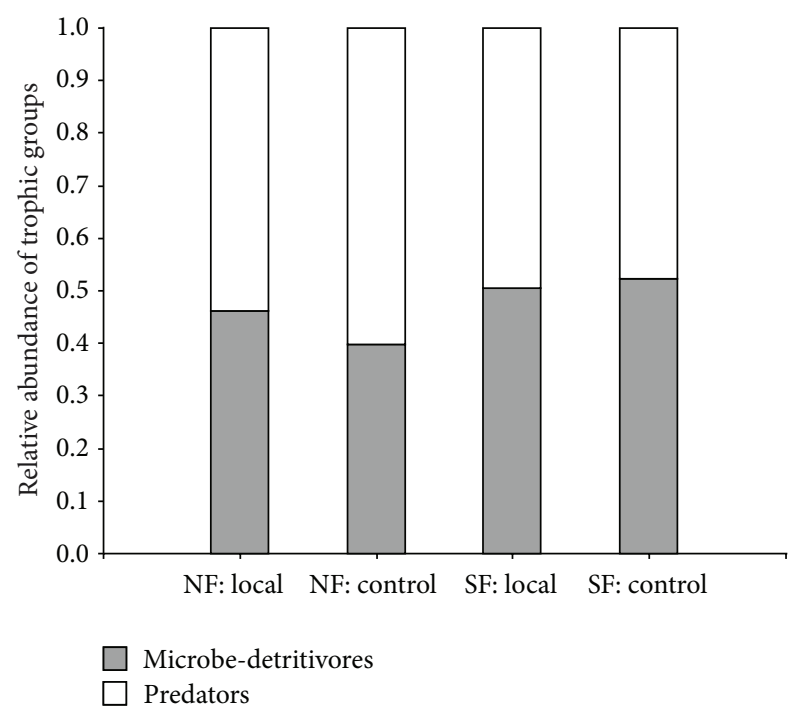

FIGURE 5: Trophic structure of decomposer fauna in native (NF) and saltcedar (SF) forests for the local and control litter.
TABLE 2: Local and control litter decomposition within native and saltcedar forests (grams of initial mass remaining at the end of the experiment, with standard deviation given in brackets). Different letters indicate significant differences $(P<0.05)$.

\begin{tabular}{lclc}
\hline Forest & Litter & \multicolumn{1}{c}{ Remaining litter $(\mathrm{g})$} \\
\hline \multirow{2}{*}{ Native } & Local & $3.12(0.48)$ & $\mathrm{a}$ \\
& Control & $3.67(0.32)$ & $\mathrm{a}$ \\
\multirow{3}{*}{ Saltcedar } & Local & $3.05(0.34)$ & $\mathrm{a}$ \\
& Control & $4.37(0.67)$ & $\mathrm{b}$ \\
\hline
\end{tabular}

proportion than in the previous case. Only one of the five native species ( $G$. decorticans) was found to significantly contribute cellulose to litter because it has phloem fiber caps outside the bundles in the xylem tissue of leaves and twigs. Cellulose content was the highest in saltcedar leaves, because the most abundant tissue is parenchymatous, which consisted of small cells with a thick cell wall. Saltcedar leaves had a very low proportion of lignin and tannins.

\section{Discussion and Conclusions}

We investigated the effects of saltcedar invasion on litter decomposition process in four sites with the same soil type and land-use history until approximately 45 years before sampling; therefore, we assume that the principal differences between sites are attributable mainly to saltcedar invasion.

The invasion of saltcedar produced an increase in abundance of Collembola, Acari, and total mesofauna, irrespective of litter type. The increase in collembolan abundance could be attributed to the higher quality of saltcedar litter than that of the native forest litter, which fosters fungal and microbial biomass growth [45]. Our findings agree with those of Robson et al. [46], who indicated that abundance of Collembola in pine plantations was significantly higher than in native eucalypt woodland. However, those authors found that high abundances of Collembola in plantations were associated with lower litter quality, which is in contrast with our interpretation.

We consider that the higher densities of mites in the invaded forest than in the native forest, in both litters, would be due to the absence of competition. According to the intermediate disturbance hypothesis $[47,48]$, the impact of invasion can be viewed as a moderate stress where high abundance is maintained by a decrease in the probability of competitive exclusion [38]. 
The relative proportion of trophic groups was not markedly affected by saltcedar invasion. In this forest, microbe-detritivores showed a slight increase in their relative proportions in both litter types. This shows that trophic group structure is relatively stable and is not strongly altered by saltcedar invasion or by the introduction of a new resource of higher quality than that present in the native forest. This pattern was also observed in grass plots where detritivore numbers showed little difference between invaded and uninvaded communities, despite plant litter changes induced by invasion [49].

Saltcedar invasion is expected to affect plant litter decomposition because it can influence decomposer community and litter quality, the two factors that determine litter decomposition rates under a given climatic condition. In the present study, to test the influence of soil fauna on decomposition, we placed the same litter type (control litter) in both forests to exclude the effect of litter quality; we found an inverse relationship between abundance of mites, collembolans, and total mesofauna and decomposition. Decomposition was lower in the saltcedar forest, where all taxa showed the highest abundances, than in the native forest. This shows that the abundance of decomposer organisms per se does not imply proper functioning of litter decomposition process. In other words, increased abundance of decomposer fauna does not necessarily accelerate decomposition. These results are consistent with those of Kaneko and Salamanca [50], who found that faunal abundances in single-species litterbags were not correlated with mass loss. Our findings also agree with those of Standish [11], who found that rates of litter decomposition of an invasive herbaceous weed were not associated with an increase in the abundance of Collembola and Acari. It has been suggested that the maintenance of a specific function is the result of the combination of specific taxa, and richness per se may not ensure ecosystem functioning $[13,51]$. Our results also show that abundance per se does not ensure ecosystem functioning. An abundant decomposer community may lack specific taxa required to perform a specific function in the decomposition process.

Decomposition of the local litter was similar in native and saltcedar forests, showing that both ecosystems have a decomposer fauna adapted to efficiently decompose the autochthonous litter. However, we observed that saltcedar litter had lower lignin and tannin content and higher cellulose content than the litter of the five dominant native species. The relatively higher litter quality of saltcedar in comparison with the native species is in agreement with previous studies $[52,53]$. It is known that litter decomposition is negatively influenced by slowly degradable compounds (lignin and tannins) and positively affected by more degradable compounds (cellulose) [54]. Overall, the litter quality of saltcedar would be better than that of the native litter and, therefore, saltcedar litter could be expected to decompose faster than native litter. However, both litter types were decomposed in the same amount, each at their original sites. The absence of differences can be explained in terms of a compensatory effect of litter quality and heterogeneity. We propose a compensation produced by a lower quality but more heterogeneous litter in the native forest and a higher quality but almost homogeneous litter in the invaded forest. It has been demonstrated that litter produced from mixtures of several plant species decomposes faster than material taken from isolated species $[50,55]$.

It has been suggested that invasive species often maintain higher concentrations of leaf nitrogen [17] and therefore decompose more rapidly than native species. Ehrenfeld et al. [16] found that an invasive species with higher litter quality than the native species decomposed more rapidly, whereas the invasive species with lower litter quality than the native species decomposed more slowly. Based on our results, we suggest that, although the physical and chemical features of saltcedar litter might contribute to its faster decomposition, that effect would be offset by the low microhabitat complexity of saltcedar litter that affected decomposer community, as discussed in the previous paragraph.

The greatest differences in decomposition were reported to occur between invaded and uninvaded sites rather than between native and exotic species [11, 17]. Ashton et al. [17] suggested that the differences might have resulted from differences in the decomposer community. Our results support this assumption, since we could demonstrate the important influence of fauna on decomposition, experimentally excluding the effect of litter quality. It can therefore be concluded that the "site" effect can be in part explained in terms of changes in the decomposer community. However, the effects of other factors should be explored.

In the invaded forest, the decomposition rate of the control litter was much lower than that of the saltcedar litter, which highlights the high specialization of the decomposer fauna in the use of saltcedar litter and its low capacity to adapt to a new resource, even to a high quality one. In the native forest, control litter also decomposed at a slower rate than native litter (without significant differences) but the rate was higher than that of the control in the invaded forest. The introduction of a resource of higher quality than the local one would have a negative effect on decomposition in both ecosystems, but much pronounced in the invaded forest. This finding also supports the conclusion that decomposer fauna would be an important driver of litter decomposition in forested ecosystems, together with litter quality and heterogeneity.

4.1. Implication for Management. Considering the low efficiency of the soil fauna to decompose a new resource observed in the invaded forest, in a scenario of native forest restoration, in which new species are incorporated, nutrient cycling could be affected, impoverishing the soil system and ultimately reducing nutrient availability. Accordingly, the question arises as to how much time is needed to allow the restoration of the native mesofaunal community and ecosystem functioning. It is therefore important to develop strategies that allow the restoration of the whole ecosystem, considering not only plants but also soil fauna and ecosystems processes.

Conservation managers are increasingly unable to remove all nonnative species from ecosystems and, indeed, such species have become important components of many systems, providing habitat or resources for other species 
[56]. Several authors have also argued that nonnative species will have an important role in providing ecosystem services in the future [57]. A suitable goal for some systems is likely to be their maintenance in a hybrid state, where some nonnative species are accepted as part of the system [57]. In agreement with this viewpoint, our results show that each forest has evolved to be efficient in the decomposition of its own litter, which suggests, according to the concept of hybrid ecosystem, that each one ensures nutrient cycling and nutrient availability for the vegetation. Clearly, management decisions have to consider both the adverse effects of harmful invasive species and the positive impacts of species that play important roles that might otherwise be lost in degraded systems. Such decisions will depend significantly on cultural values about nativeness and exoticism and the ways in which such viewpoints change in the coming decades [57].

\section{Conflict of Interests}

The authors declare that there is no conflict of interests regarding the publication of this paper.

\section{Acknowledgments}

This work was financially supported by Secretaría de Ciencia y Técnica of the National University of Río Cuarto, Agencia Nacional de Promoción Científica y Técnológica (PICTb$\mathrm{N}^{\circ} 2175$ ), and Consejo Nacional de Investigaciones Científicas y Técnicas (CONICET). J. Brasca corrected the English style.

\section{References}

[1] E. Zavaleta, "The economic value of controlling an invasive shrub," Ambio, vol. 29, no. 8, pp. 462-467, 2000.

[2] T. A. Kennedy and S. E. Hobbie, "Saltcedar (Tamarix ramosissima) invasion alters organic matter dynamics in a desert stream," Freshwater Biology, vol. 49, no. 1, pp. 65-76, 2004.

[3] E. Natale, Evaluación del Riesgo de invasión por Tamariscos en ambientes naturales y seminaturales de la República Argentina [Ph.D. thesis], Universidad Nacional de Río Cuarto, Río Cuarto, Argentina, 2010.

[4] E. P. Glenn and P. L. Nagler, "Comparative ecophysiology of Tamarix ramosissima and native trees in western U.S. riparian zones," Journal of Arid Environments, vol. 61, no. 3, pp. 419-446, 2005.

[5] J. Lovich, "A brief overview of the impact of tamarisk infestation on native plants and animals," in Proceedings of the Saltcedar Management Workshop, J. DiTomaso and C. E. Bell, Eds., pp. 13-15, University of California Cooperative Extension, Hollister, Calif, USA, 1996.

[6] C. G. Ladenburger, A. L. Hild, D. J. Kazmer, and L. C. Munn, "Soil salinity patterns in Tamarix invasions in the Bighorn Basin, Wyoming, USA," Journal of Arid Environments, vol. 65, no. 1, pp. 111-128, 2006.

[7] C. J. De Loach, R. L. Carruthers, J. E. Lovich, T. L. Dudley, and S. D. Smith, "Ecological interactions in the biological control of salt cedar (Tamarix spp.) in the United States: towards a new understanding," in Proceedings of the 10th International Symposium on Biological Control on Weeds, pp. 819-873, Montana State University Press, Bozeman, Mont, USA, 2000.
[8] J. C. Stromberg, M. K. Chew, P. L. Nagler, and E. P. Glenn, "Changing perceptions of change: the role of scientists in tamarix and river management," Restoration Ecology, vol. 17, no. 2, pp. 177-186, 2009.

[9] C. Pritekel, A. Whittemore-Olson, N. Snow, and J. C. Moore, "Impacts from invasive plant species and their control on the plant community and belowground ecosystem at Rocky Mountain National Park, USA," Applied Soil Ecology, vol. 32, no. 1, pp. 132-141, 2006.

[10] J. C. Moore, E. L. Berlow, D. C. Coleman et al., "Detritus, trophic dynamics and biodiversity," Ecology Letters, vol. 7, no. 7, pp. 584600, 2004.

[11] R. J. Standish, "Impact of an invasive clonal herb on epigaeic invertebrates in forest remnants in New Zealand," Biological Conservation, vol. 116, no. 1, pp. 49-58, 2004.

[12] J. G. Ehrenfeld and N. Scott, "Invasive species and the soil: effects on organisms and ecosystem processes," Ecological Applications, vol. 11, no. 5, pp. 1259-1260, 2001.

[13] J. Belnap, S. L. Phillips, S. K. Sherrod, and A. Moldenke, "Soil biota can change after exotic plant invasion: does this affect ecosystem processes?" Ecology, vol. 86, no. 11, pp. 3007-3017, 2005.

[14] B. E. Wolfe and J. N. Klironomos, "Breaking new ground: soil communities and exotic plant invasion," BioScience, vol. 55, no. 6, pp. 477-487, 2005.

[15] A. M. Keith, R. van der Wal, R. W. Brooker, G. H. R. Osler, S. J. Chapman, and D. F. R. P. Burslem, "Birch invasion of heather moorland increases nematode diversity and trophic complexity," Soil Biology and Biochemistry, vol. 38, no. 12, pp. 3421-3430, 2006.

[16] J. G. Ehrenfeld, P. Kourtev, and W. Huang, "Changes in soil functions following invasions of exotic understory plants in deciduous forests," Ecological Applications, vol. 11, no. 5, pp. 1287-1300, 2001.

[17] I. W. Ashton, L. A. Hyatt, K. M. Howe, J. Gurevitch, and M. T. Lerdau, "Invasive species accelerate decomposition and litter nitrogen loss in a mixed deciduous forest," Ecological Applications, vol. 15, no. 4, pp. 1263-1272, 2005.

[18] G. González and T. R. Seastedt, "Soil fauna and plant litter decomposition in tropical and subalpine forests," Ecology, vol. 82, no. 4, pp. 955-964, 2001.

[19] R. Aerts, "Climate, leaf litter chemistry and leaf litter decomposition in terrestrial ecosystems: a triangular relationship," Oikos, vol. 79, no. 3, pp. 439-449, 1997.

[20] P. Lavelle, E. Blanchart, A. Martin et al., "A hierarchical model for decomposition in terrestrial ecosystems: application to soils of the humid tropics," Biotropica, vol. 25, no. 2, pp. 130-150, 1993.

[21] M. J. Swift, O. W. Heal, and J. M. Anderson, Decomposition in Terrestrial Ecosystems, vol. 5 of Studies in Ecology, Blackwell, Oxford, UK, 1979.

[22] B. R. Taylor, D. Parkinson, and W. F. J. Parsons, "Nitrogen and lignin content as predictors of litter decay rates: a microcosm test," Ecology, vol. 70, no. 1, pp. 97-104, 1989.

[23] J. M. Melillo, J. D. Aber, and J. F. Muratore, "Nitrogen and lignin control of hardwood leaf litter decomposition dynamics.", Ecology, vol. 63, no. 3, pp. 621-626, 1982.

[24] C. E. Prescott, "Do rates of litter decomposition tell us anything we really need to know?" Forest Ecology and Management, vol. 220, no. 1-3, pp. 66-74, 2005.

[25] G. Barajas-Guzmán and J. Alvarez-Sánchez, “The relationships between litter fauna and rates of litter decomposition in a 
tropical rain forest," Applied Soil Ecology, vol. 24, no. 1, pp. 91100,2003

[26] D. H. Wall and J. C. Moore, "Interactions underground: soil biodiversity, mutualism, and ecosystem processes," BioScience, vol. 49, no. 2, pp. 109-117, 1999.

[27] R. A. Hansen, "Red oak litter promotes a microarthropod functional group that accelerates its decomposition," Plant and Soil, vol. 209, no. 1, pp. 37-45, 1999.

[28] J. J. Cantero, "Los humedales del centro sur de Córdoba. Parte B. Comunidades vegetales y aspectos fitosociológicos relacionados," in Aguas Superficiales y Subterráneas en el sur de Córdoba: una perspectiva geoambiental, M. Blarasin, S. Degiovanni, A. Cabrera, and M. Villegas, Eds., pp. 283-294, UniRío, Río Cuarto, Argentina, 2005.

[29] Soil Survey Staff, Keys to Soil Taxonomy, USDA-Natural Resources Conservation Service, Washington, DC, USA, 11th edition, 2010.

[30] DACyTSEM, Los Suelos. Nivel de Reconocimiento 1:500.000, Agencia Córdoba e INTA Manfredi, Córdoba, Argentina, 2003.

[31] Servicio de Agrometeorología UNRC, "Facultad de Agronom $\varphi$ a y Veterinaria," Universidad Nacional de Río Cuarto, Argentina, 2010.

[32] L. Sacchi, Impacto de los bosques de tamarisco (Tamarix ramosissima) sobre el sistema suelo en el sur de la provincia de Córdoba [Ph.D. thesis], Universidad Nacional de Río Cuarto, Río Cuarto, Argentina, 2009.

[33] L. Calle, Resumen de Historia de Río Cuarto, Puma, Río Cuarto, Argentina, 1977.

[34] D. A. Marini, Bases para la restauración de sitios afectados por tamarisco (Tamarix ramosissima) en el sur de la provincia de Córdoba [Ph.D. thesis], Universidad Nacional de Río Cuarto, Río Cuarto, Argentina, 2009.

[35] D. Coleman, D. A. Crossley Jr., and P. F. Hendrix, Fundamentals of Soil Ecology, Elsevier Academic Press, California, Calif, USA, 2nd edition, 2004.

[36] A. Domínguez, J. C. Bedano, and A. R. Becker, "Negative effects of no-till on soil macrofauna and litter decomposition in Argentina as compared with natural grasslands," Soil and Tillage Research, vol. 110, no. 1, pp. 51-59, 2010.

[37] J. M. F. Johnson, N. W. Barbour, and S. L. Weyers, "Chemical composition of crop biomass impacts its decomposition," Soil Science Society of America Journal, vol. 71, no. 1, pp. 155-162, 2007.

[38] J. C. Bedano, M. P. Cantú, and M. E. Doucet, "Influence of three different land management practices on soil mite (Arachnida: Acari) densities in relation to a natural soil," Applied Soil Ecology, vol. 32, no. 3, pp. 293-304, 2006.

[39] S. Scheu, D. Albers, J. Alphei et al., "The soil fauna community in pure and mixed stands of beech and spruce of different age: trophic structure and structuring forces," Oikos, vol. 101, no. 2, pp. 225-238, 2003.

[40] S. Scheu and M. Falca, "The soil food web of two beech forests (Fagus sylvatica) of contrasting humus type: stable isotope analysis of a macro- and a mesofauna-dominated community," Oecologia, vol. 123, no. 2, pp. 285-296, 2000.

[41] D. A. Johansen, Plant Microtechnique VI-VII, McGraw-Hill, New York, NY, USA, 1940.

[42] J. A. di Rienzo, A. W. Guzmán, and F. Casanoves, "A multiplecomparisons method based on the distribution of the root node distance of a binary tree," Journal of Agricultural, Biological, and Environmental Statistics, vol. 7, no. 2, pp. 129-142, 2002.
[43] M. M. Rahman and Z. Govindarajulu, "A modification of the test of Shapiro and Wilk for normality," Journal of Applied Statistics, vol. 24, no. 2, pp. 219-235, 1997.

[44] J. A. di Rienzo, F. Casanoves, M. G. Balzarini, L. González, M. Tablada, and C. W. Robledo, "InfoStat versión 2012. Grupo InfoStat," FCA, Universidad Nacional de Córdoba, Argentina, 2012.

[45] S. Gillet and J. Ponge, "Changes in species assemblages and diets of Collembola along a gradient of metal pollution," Applied Soil Ecology, vol. 22, no. 2, pp. 127-138, 2003.

[46] T. C. Robson, A. C. Baker, and B. R. Murray, "Differences in leaflitter invertebrate assemblages between radiata pine plantations and neighbouring native eucalypt woodland," Austral Ecology, vol. 34, no. 4, pp. 368-376, 2009.

[47] J. P. Grime, Plant Strategies and Vegetation Processes, Wiley, New York, NY, USA, 1979.

[48] M. Huston, "A general hypothesis of species diversity," The American Naturalist, vol. 113, no. 1, pp. 81-101, 1979.

[49] J. Belnap and S. L. Phillips, "Soil biota in an ungrazed grassland: response to annual grass (Bromus tectorum) invasion," Ecological Applications, vol. 11, no. 5, pp. 1261-1275, 2001.

[50] N. Kaneko and E. F. Salamanca, "Mixed leaf litter effects on decomposition rates and soil microarthropod communities in an oak-pine stand in Japan," Ecological Research, vol. 14, no. 2, pp. 131-138, 1999.

[51] D. A. Wardle, Communities and Ecosystems: Linking the Aboveground and Belowground Components, Princeton University Press, Princeton, NJ, USA, 2002.

[52] T. M. Tibbets and M. C. Molles Jr., "C:N:P stoichiometry of dominant riparian trees and arthropods along the Middle Rio Grande," Freshwater Biology, vol. 50, no. 11, pp. 1882-1894, 2005.

[53] C. R. Whitcraft, L. A. Levin, D. Talley, and J. A. Crooks, "Utilization of invasive tamarisk by salt marsh consumers," Oecologia, vol. 158, no. 2, pp. 259-272, 2008.

[54] G. Loranger, J. Ponge, D. Imbert, and P. Lavelle, "Leaf decomposition in two semi-evergreen tropical forests: influence of litter quality," Biology and Fertility of Soils, vol. 35, no. 4, pp. 247-252, 2002.

[55] M. J. I. Briones and P. Ineson, "Decomposition of eucalyptus leaves in litter mixtures," Soil Biology and Biochemistry, vol. 28, no. 10-11, pp. 1381-1388, 1996.

[56] S. D. Graves and A. M. Shapiro, "Exotics as host plants of the California butterfly fauna," Biological Conservation, vol. 110, no. 3, pp. 413-433, 2003.

[57] R. J. Hobbs, E. Higgs, and J. A. Harris, "Novel ecosystems: implications for conservation and restoration," Trends in Ecology and Evolution, vol. 24, no. 11, pp. 599-605, 2009. 

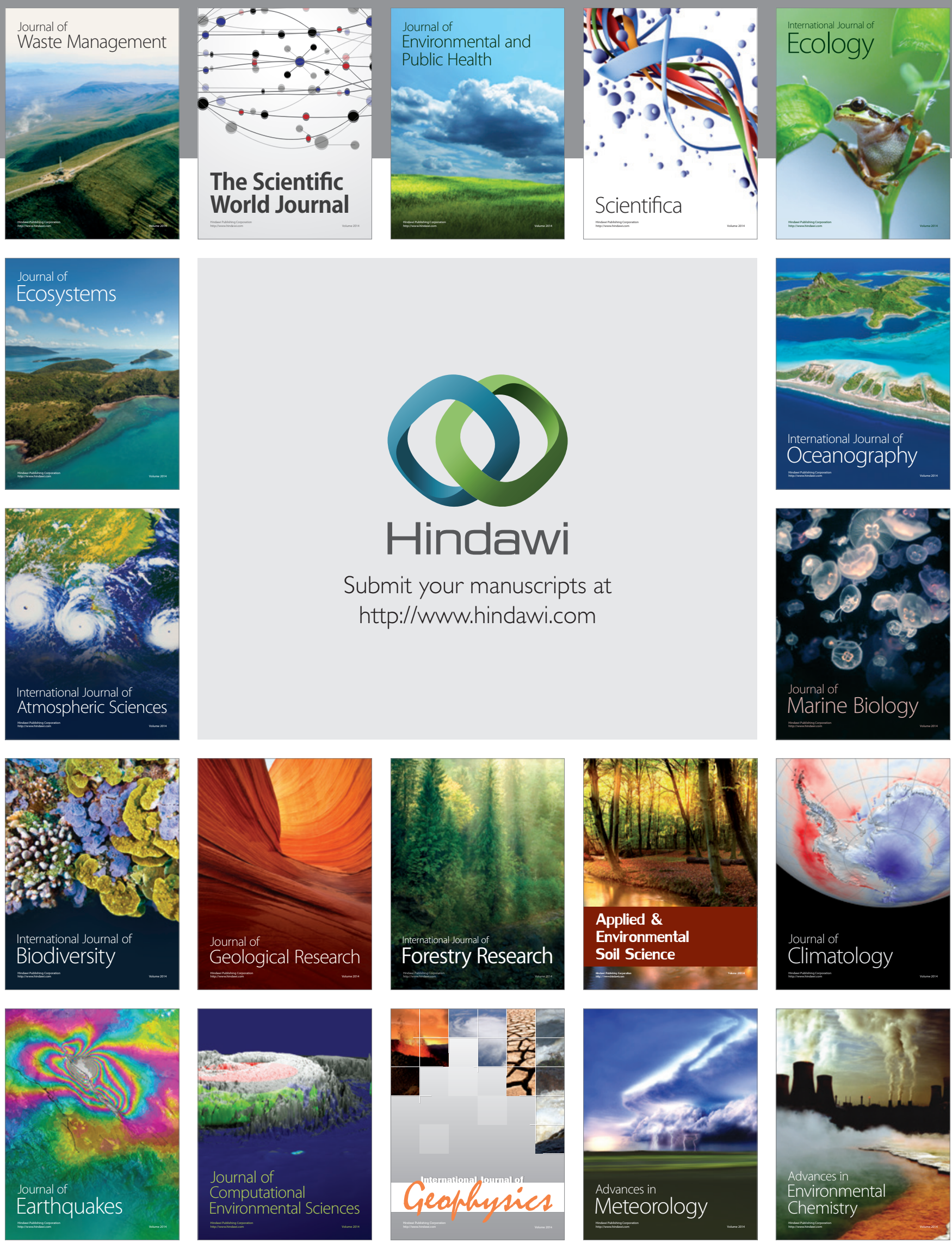